\title{
Effect of Management Practices to Tackle Tip Drying in Small Onion Due to Dew Drops in NICRA Village of Namakkal District of Tamil Nadu, India
}

\author{
C. Sharmila Bharathi* and B. Mohan ${ }^{1}$ \\ ${ }^{1}$ ICAR- Krishi Vigyan Kendra, Veterinary College and Research Institute, \\ TANUVAS, Namakkal- 637002, Tamil Nadu, India \\ ${ }^{2}$ Veterinary College and Research Institute, TANUVAS, Namakkal, Tamil Nadu, India \\ *Corresponding author
}

\begin{abstract}
A B S T R A C T
In Vadavathur village, small onion is cultivated in two main seasons viz., Early kharif and Rabi in an area of 425 ha with a productivity of 14 tonnes / ha. Small onion is mainly affected by dew drops during the month of November to January, where the minimum temperature falls between 12 to $14^{0} \mathrm{C}$ for 17 days and caused tip drying. Presence of dew drops in tip of onion leaf sheath for a long time may lead to death of terminal leaf tissue resulted in tip drying and also reduction in yield of 0.7 to 2 tonnes / ha. The tip drying of small onion due to dew drops was controlled in Vadavathur village under NICRA scheme by three methods viz., spraying of water through mobile sprinkler (T3) and by using rope method (T2) and without spray (T1). In rope method, the nylon rope was pared over the onion crop during early morning by two labourers for 2 hours / 0.4 ha area in 3 days interval. In mobile sprinkler method, Sprinkler sprinkle the water with a discharge rate of 200 LPM over the onion crop for 1 hour covered in an area of 0.4 ha on cost basis @ Rs.150/ hour in weekly intervals. By these method the dew drops present on the tip of onion leaves got fall down and washed out. Demonstration plots recorded higher yield of $13.0 \mathrm{t} / \mathrm{ha}$ compared to farmers practice of $12.3 \mathrm{t} / \mathrm{ha}$ with a B: C ratio of 3.17 and 2.31 respectively. Mobile sprinkler method as one of the climate resilience practice followed against tip drying in small onion due to dew drops in NICRA village of Namakkal district, which effectively protect the crop during adverse weather condition and also improved the quality of onion bulbs.
\end{abstract}

\section{Introduction}

Aggregatum onion (Allium cepa L. var. aggregatum Don.) is one of the oldest bulb crops known to mankind and extensively grown and consumed in Southern states of India. On global scale aggregatum onion is a minor bulb crop however in South East Asia especially in India it is a highly remunerative crop. The bulblets of aggregatum onion are smaller than bulbs of common onion (Allium сера $\mathrm{L})$. Sometimes the flowers are formed in aggregatum onion but cultivation is extensively by vegetative means (bulblets) contrast to common onion. It is famous for its pungency and its diuretic properties, relieves heat sensation, hysterical faintness, insect bites and is also heart stimulation. Small onion reproduces primarily by division of bulbs, rather than by seed. 
This makes it more similar to garlic than to common onions. It is a crop of tropical and subtropical region which are tolerant to hot and humid tropical climate, better tolerance to pest and diseases and have longer storage life than the common onion. It is also known as small onion, potato onion, underground onion, shallots, multiplier onion, nesting onions, ever-ready onion and Egyptian ground onion noted for its hardiness and early maturity than the common onion.

Aggregatum onion mainly produced in southern states of India viz., Tamil Nadu, Andhra Pradesh and South Karnataka and small parts of Orissa and Kerala. Tamil Nadu accounted for five per cent of country's area under onion and more than 70 per cent of the area is cultivated by small onion. Around 90 per cent of country's small onion is produced from Tamil Nadu and 10 per cent from Karnataka. The total area and productivity of small onion under Namakkal district was 1,997 ha and $12 \mathrm{t} / \mathrm{ha}$, respectively in 2014 . Throughout the world there is significant concern about the effects of climate change and its variability on agricultural production. Since climatic factors serve as direct inputs to agriculture, any change in climatic factors is bound to have a significant impact on crop yields and production. In developing countries, climate change will cause yield declines for the most important crops and South Asia will be particularly hard hit.

Like that climate is one of the main determinant factors for small onion production. Excessive rains, humidity, temperature, pests and disease are critical factors of risk to onion cultivation. Such adverse conditions prevailed during the early part of the onion growing season affect the crop thus leads to yield loss. In newly planted onions intensive dew can cause damage to the tender young leaf sheath and fragile bulbs. There are ways, however, to give onion against cold, dew and frost protection that are quick and easy. In Vadavathur village, small onion is cultivated in two main seasons viz., Early kharif and Rabi in an area of 425 ha with a productivity of 14 tonnes / ha. Small onion is mainly affected by dew drops during the month of November to January, where the minimum temperature falls between 12 to $14^{0} \mathrm{C}$ for 17 days and caused tip drying. Presence of dew drops in tip of onion leaf sheath for a long time may lead to death of terminal leaf tissue resulted in tip drying and also reduction in yield of 0.7 to 2 tonnes / ha. To overcome this problem, an experiment was carried out during 2012 - 2014 at Vadavathur village of Namakkal District under NICRA scheme by Krishi Vigyan Kendra.

\section{Weather and climate}

During the study period (OctoberDecember), $469.6 \mathrm{~mm}$ of rainfall was received in 13 rainy days in 2012, $639 \mathrm{~mm}$ in 10 rainy days in 2013 and $787 \mathrm{~mm}$ in 20 rainy days in 2014. Maximum monthly mean temperature was $36.6^{\circ} \mathrm{C}, 38.5^{\circ} \mathrm{C} \& 37.5^{\circ} \mathrm{C}$ and minimum was $21^{\circ} \mathrm{C}, 23.1^{\circ} \mathrm{C}$ and $23.1^{\circ} \mathrm{C}$. In 2012, 2013 and 2014 respectively. Maximum mean relative humidity was 82.8 per cent in 2012, 79 per cent in 2013 and 79.3 per cent in 2014 and minimum was 52.3 per cent in 2012, 47.8 per cent in 2013 and 51.7 per cent in 2014 at 07.22 and $14.22 \mathrm{hr}$, respectively (Table 1).

\section{Materials and Methods}

The experiment was carried out at fifteen farmer's field of Vadavathur village of Namakkal District of Tamil Nadu during Rabi season (October - December)in 2012, 2013 and 2014. Vadavathur is situated at $11.9241^{\circ} \mathrm{N}$ latitude and $78.11917^{\circ} \mathrm{E}$ longitude and at an elevation of $531 \mathrm{~m}$ above mean sea level. The soil type is red sandy loam with a $\mathrm{pH}$ of 7.9 and EC of $0.064 \mathrm{dSm}^{-1}$ with a soil nutrient 
status of low Nitrogen (188 kg/ ha), medium Phosphorus (11 kg / ha) and high Potassium (294 kg /ha).

The experiment was laid out in a Randomized Block Design which was replicated thrice. The tip drying of small onion due to dew drops was controlled in Vadavathur village panchayat under NICRA scheme by three methods viz., a). Spraying of water through mobile sprinkler (T3) and b). Using rope method (T2) and No spray (T1). Farmers could take mobile sprinkler on hire basis from Custom-hiring centre for farm equipment developed at Vadavathur under NICRA Scheme by KVK, Namakkal.

In rope method, the nylon rope was pared over the onion crop during early morning by two labourers for 2 hours/ 0.4 ha area in 3 days interval. In mobile sprinkler method, sprinkler sprinkles the water with a discharge rate of 200 LPM over the onion crop for 1 hour covered in an area of 0.4 ha on cost basis @ Rs.150/ hour in weekly intervals. Then soil test based macro and micro nutrient application and need based plant protection measures against pest and diseases were carried out uniformly during the period of crop growth as recommended by TNAU (Anonymous, 2013). IIHR vegetable booster applied as a foliar spray @ 5gm per litre of water along with sticking agent at 30 and 45 days after sowing. In addition regular training of the farmers and trainers in improved crop management practices is provided by $\mathrm{KVK}$ then and there.

\section{Results and Discussion}

The management of tip drying shows significant effect in the bulb polar diameter of aggregatum onion. The highest bulb polar diameter was recorded in mobile sprinkler method T3 $(3.94 \mathrm{~cm}$ in 2012, $4.06 \mathrm{~cm}$ in 2013 \&2014) when compared to rope method T2
$(3.48,3.70 \& 3.76 \mathrm{~cm})$ whereas the lowest bulb polar diameter was observed in control T1 (3.10, 3.25 and $3.29 \mathrm{~cm}$ ) during the Rabi season of 2012, 2013 and 2014 respectively (Table 2 \& Fig.1). This might be due to the quick removal of dew drops in the onion leaf sheath during leaf as well as bulb developmental stage by overhead irrigation through mobile sprinkler which is done with sprinkler mounted above the crop canopy. This techniques could effectively prevents the tip drying in onion leaf sheath may be due to the favorable effect on removal of dew drops and maintains many physiological process and cellular function within plants. In addition, foliar application of IIHR vegetable special play an essential role in improving plant growth, through the biosynthesis of endogenous hormones which is responsible for promotion of plant growth (Bhatt et al., 2004; Hansch and Mendel, 2009). Increase in number of leaves per plant may be attributed to the role of micronutrients $(\mathrm{Zn}, \mathrm{B})$ in cell division, meristematic activity of plant tissue and expansion of cells (Patil et al., 2009).This is in accordance with the findings of Rohini and Paramaguru (2016).

Generally climatic changes influence the severity of environmental stress imposed on vegetable crops. The response of plants to environmental stresses depends on the plant developmental stage, the length and severity of the stress (Bray, 2002).Onion crop is sensitive to dew drops, it affects the leaf developmental stage. In the present study, the highest bulb equatorial diameter was recorded in T3(3.93, 4.13 and $4.21 \mathrm{~cm})$ when compared to $\mathrm{T} 2(3.93,3.86$ and $3.92 \mathrm{~cm})$ during the Rabi season of 2012, 2013 and 2014 whereas the lowest bulb equatorial diameter was observed in $\mathrm{T} 1(3.52,3.30$ and $3.20 \mathrm{~cm}$ ) (Table $3 \&$ Fig.1).This might be due to the removal of dew drops in the onion leaf sheath by mobile sprinkler method thus positively maintains the optimum plant as well as soil temperature, 
relative humidity and plant health management prevailed during the initiation and completion of bulbs. The results are in accordance with finding of Jilani (2004). Maximum bulb yield was noted from T3 during Rabi season recording more yield/plant (21.7 g, $21 \mathrm{~g}$ and $20.9 \mathrm{~g}$ ) followed by T2 (Table 4 \& Fig.1). It is interesting to note that yield attributing characters like polar diameter and equatorial diameter were higher in T3 during rabi season crop than $\mathrm{T} 2$.

This might be the reason for the increase in the bulb yield/ plant in rabi season which ultimately increased the yield per unit area. These results are in accordance with the finding of Aramiratham (2000), Boyhan et al., (2008) and Anisuzzaman et al., (2009) in onion. In $\mathrm{T} 1$ treatment, inadequate removal of dew drops leads to lower yields. In this period temperature recorded was between 21.90$28.08^{\circ} \mathrm{C}$. Abnormal weather events such as fall in temperatures have profound influence on the performance of the crop. During the crop seasons of Rabi2012, 2013 and 2014onion crop was damaged due to abnormal temperatures and rainfall. Management of tip drying was found to have significant effect on the bulb yield per hectare of aggregatum onion. The highest bulb yield per hectare was recorded in T3 with bulb yield of 13.3, 13.6 and $13.5 \mathrm{t} \mathrm{ha}^{-1}$ followed by T2 (12.3, 12.4 and $12.3 \mathrm{t} \mathrm{ha}^{-1}$ ) during Rabi 2012, 2013 and 2014 respectively (Table 5 \& Fig.1). The lowest bulb yield (12.1, 11.1 and $10.7 \mathrm{tha}^{-1}$ ) was observed in $\mathrm{T} 1$ (control). The findings of Ud-deen (2008) supported that increased yield maybe because of difference in yield components as bulb volume, average weight of the bulbs and crop stand. Secondly it may be because onion leaf sheath getting free of tip drying due to easy and timely removal of dew drops by mobile sprinkler method.

Table.1 Weather parameters prevailed during cropping period

\begin{tabular}{|c|c|c|c|c|c|c|}
\hline \multirow[t]{2}{*}{ Month/Year } & \multicolumn{2}{|c|}{$\begin{array}{c}\text { Temperature } \\
\left({ }^{\circ} \mathrm{C}\right)\end{array}$} & \multicolumn{2}{|c|}{$\begin{array}{c}\text { Relative } \\
\text { Humidity }\end{array}$} & \multirow[t]{2}{*}{$\begin{array}{c}\text { Rainfall } \\
\text { (mm) }\end{array}$} & \multirow[t]{2}{*}{$\begin{array}{c}\text { Rainy } \\
\text { days }\end{array}$} \\
\hline & $\operatorname{Max}$ & Min & Max & Min & & \\
\hline \multicolumn{7}{|c|}{2012} \\
\hline October 2012 & 33.40 & 22.30 & 88.50 & 78.80 & 243.8 & 13 \\
\hline November 2012 & 33.40 & 21.90 & 80.60 & 53.80 & 2 & 0 \\
\hline December 2012 & 33.30 & 22.40 & 83.50 & 51.80 & 0 & 0 \\
\hline Average/Total & 36.6 & 21.0 & 82.8 & 52.3 & 469.60 & 13 \\
\hline \multicolumn{7}{|c|}{2013} \\
\hline October 2013 & 38.70 & 23.60 & 83.90 & 42.50 & 170 & 5 \\
\hline November 2013 & 37.5 & 19.3 & 79.1 & 47.3 & 61 & 1 \\
\hline December 2013 & 32.70 & 19.7 & 81.20 & 48.8 & 38 & 4 \\
\hline Average/Total & 38.5 & 23.1 & 79.0 & 47.8 & 639 & 10 \\
\hline \multicolumn{7}{|c|}{2014} \\
\hline October 2014 & 34.7 & 23.7 & 83.0 & 55.1 & 136 & 12 \\
\hline November 2014 & 32.80 & 23.5 & 79.5 & 52.6 & 69 & 6 \\
\hline December 2014 & 31.0 & 24.6 & 78.4 & 54.9 & 61 & 2 \\
\hline Average/Total & 37.5 & 23.1 & 79.3 & 51.7 & 787 & 20 \\
\hline
\end{tabular}


Table.2 Effect of dew drops management practices on polar diameter of small onion bulb $(\mathrm{cm})$

\begin{tabular}{|l|c|c|c|c|c|c|c|c|c|c|}
\hline Field & \multicolumn{9}{|c|}{ Mobile sprinkler method (T3) } & \multicolumn{3}{|c|}{ Rope method (T2) } & \multicolumn{3}{c|}{ Control (T1) } \\
\hline Number & Rabi12 & Rabi 13 & Rabi 14 & Rabi 12 & Rabi 13 & Rabi 14 & Rabi 12 & Rabi 13 & Rabi 14 \\
\hline Field 1 & 3.93 & 4.17 & 4.07 & 3.83 & 3.63 & 3.77 & 3.17 & 3.10 & 3.43 \\
\hline Field 2 & 3.93 & 3.93 & 4.10 & 3.57 & 3.53 & 3.80 & 3.23 & 3.17 & 3.57 \\
\hline Field 3 & 3.97 & 4.13 & 4.03 & 3.73 & 3.70 & 3.73 & 3.17 & 3.53 & 3.40 \\
\hline Field 4 & 3.93 & 3.97 & 3.97 & 3.53 & 3.87 & 3.77 & 3.30 & 3.03 & 3.57 \\
\hline Field 5 & 3.90 & 3.87 & 4.10 & 3.60 & 3.83 & 3.73 & 3.00 & 3.47 & 3.10 \\
\hline Field 6 & 3.93 & 4.10 & 3.73 & 3.43 & 3.87 & 3.80 & 2.93 & 3.07 & 3.00 \\
\hline Field 7 & 3.90 & 4.03 & 3.83 & 3.30 & 3.83 & 3.87 & 2.97 & 3.67 & 3.00 \\
\hline Field 8 & 4.20 & 4.13 & 4.10 & 3.47 & 3.83 & 3.70 & 3.27 & 3.33 & 2.97 \\
\hline Field 9 & 3.93 & 4.03 & 4.17 & 3.33 & 3.67 & 3.57 & 3.37 & 3.17 & 3.47 \\
\hline Field 10 & 3.97 & 4.00 & 4.17 & 3.43 & 3.67 & 3.77 & 3.27 & 3.07 & 3.27 \\
\hline Field 11 & 3.97 & 4.13 & 4.27 & 3.37 & 3.73 & 3.83 & 2.97 & 3.27 & 3.23 \\
\hline Field 12 & 3.97 & 4.20 & 4.37 & 3.30 & 3.47 & 3.80 & 3.00 & 3.17 & 3.30 \\
\hline Field 13 & 3.93 & 4.00 & 4.03 & 3.40 & 3.53 & 3.70 & 2.93 & 3.30 & 3.37 \\
\hline Field 14 & 3.93 & 4.07 & 4.00 & 3.47 & 3.63 & 3.90 & 3.10 & 3.10 & 3.43 \\
\hline Field 15 & 3.67 & 4.23 & 4.03 & 3.47 & 3.80 & 3.73 & 2.90 & 3.33 & 3.33 \\
\hline Mean & $\mathbf{3 . 9 4}$ & $\mathbf{4 . 0 6}$ & $\mathbf{4 . 0 6}$ & $\mathbf{3 . 4 8}$ & $\mathbf{3 . 7 0}$ & $\mathbf{3 . 7 6}$ & $\mathbf{3 . 1 0}$ & $\mathbf{3 . 2 5}$ & $\mathbf{3 . 2 9}$ \\
\hline SED & 0.10 & 0.12 & 0.17 & 0.14 & 0.15 & 0.10 & 0.11 & 0.13 & 0.16 \\
\hline CD(p=05) & 0.21 & 0.24 & 0.35 & 0.29 & 0.30 & 0.20 & 0.22 & 0.26 & 0.34 \\
\hline
\end{tabular}

Table.3 Effect of dew drops management practices on equatorial diameter of small onion bulb $(\mathrm{cm})$

\begin{tabular}{|l|c|c|c|c|c|c|c|c|c|}
\hline Field & \multicolumn{3}{|c|}{ Mobile sprinkler method } & \multicolumn{3}{|c|}{ Rope method } & \multicolumn{3}{c|}{ Control } \\
\hline Number & Rabi12 & Rabi 13 & Rabi 14 & Rabi 12 & Rabi 13 & Rabi 14 & Rabi 12 & Rabi 13 & Rabi 14 \\
\hline Field 1 & 4.33 & 4.07 & 4.17 & 4.00 & 3.93 & 3.97 & 3.73 & 3.50 & 3.33 \\
\hline Field 2 & 4.30 & 4.03 & 4.03 & 4.03 & 3.87 & 3.93 & 3.63 & 3.27 & 3.43 \\
\hline Field 3 & 4.37 & 4.10 & 4.23 & 4.00 & 3.80 & 3.93 & 3.30 & 3.27 & 3.27 \\
\hline Field 4 & 4.27 & 4.13 & 4.13 & 4.00 & 4.03 & 3.87 & 3.47 & 3.57 & 3.23 \\
\hline Field 5 & 4.07 & 4.10 & 4.27 & 3.93 & 3.93 & 3.90 & 3.43 & 3.30 & 3.13 \\
\hline Field 6 & 4.07 & 4.30 & 4.27 & 4.07 & 4.03 & 3.93 & 3.73 & 3.40 & 3.23 \\
\hline Field 7 & 4.13 & 4.30 & 4.50 & 4.10 & 3.90 & 3.97 & 3.67 & 3.17 & 3.20 \\
\hline Field 8 & 4.03 & 4.10 & 4.10 & 3.97 & 3.83 & 3.97 & 3.60 & 3.37 & 3.13 \\
\hline Field 9 & 4.23 & 4.17 & 4.07 & 3.73 & 3.90 & 4.00 & 3.60 & 3.27 & 3.10 \\
\hline Field 10 & 4.33 & 4.13 & 4.20 & 3.70 & 3.80 & 3.97 & 3.47 & 3.20 & 3.17 \\
\hline Field 11 & 4.37 & 4.27 & 4.27 & 3.90 & 3.83 & 3.83 & 3.47 & 3.17 & 3.17 \\
\hline Field 12 & 4.30 & 4.10 & 4.23 & 4.00 & 3.83 & 3.87 & 3.57 & 3.03 & 3.27 \\
\hline Field 13 & 4.17 & 4.03 & 4.33 & 3.97 & 3.77 & 3.93 & 3.67 & 3.33 & 3.53 \\
\hline Field 14 & 4.13 & 4.07 & 4.13 & 3.80 & 3.67 & 3.87 & 3.27 & 3.27 & 3.00 \\
\hline Field 15 & 3.97 & 4.00 & 4.27 & 3.87 & 3.80 & 3.87 & 3.23 & 3.40 & 2.90 \\
\hline Mean & $\mathbf{3 . 9 3}$ & $\mathbf{4 . 1 3}$ & $\mathbf{4 . 2 1}$ & $\mathbf{3 . 9 3}$ & $\mathbf{3 . 8 6}$ & $\mathbf{3 . 9 2}$ & $\mathbf{3 . 5 2}$ & $\mathbf{3 . 3 0}$ & $\mathbf{3 . 2 0}$ \\
\hline SED & 0.08 & 0.10 & 0.14 & 0.08 & 0.09 & 0.12 & 0.14 & 0.12 & 0.14 \\
\hline CD(p=05) & 0.17 & 0.21 & 0.28 & 0.17 & 0.19 & 0.25 & 0.28 & 0.25 & 0.29 \\
\hline
\end{tabular}


Table.4 Effect of dew drops management practices on yield/plant (gram)

\begin{tabular}{|c|c|c|c|c|c|c|c|c|c|}
\hline \multirow{2}{*}{$\begin{array}{l}\text { Field } \\
\text { Number }\end{array}$} & \multicolumn{3}{|c|}{ Mobile sprinkler method } & \multicolumn{3}{|c|}{ Rope method } & \multicolumn{3}{|c|}{ Control } \\
\hline & Rabi12 & Rabi 13 & Rabi 14 & Rabi 12 & Rabi 13 & Rabi 14 & Rabi 12 & Rabi 13 & Rabi 14 \\
\hline Field 1 & 19.2 & 19.6 & 20.1 & 15.8 & 16.2 & 16.4 & 15.3 & 15.5 & 15.3 \\
\hline Field 2 & 20.5 & 20.4 & 20.1 & 15.9 & 15.9 & 16.2 & 15.7 & 15.8 & 15.8 \\
\hline Field 3 & 20.6 & 19.8 & 19.9 & 16.0 & 16.1 & 16.2 & 15.7 & 15.9 & 15.8 \\
\hline Field 4 & 21.8 & 21.8 & 21.8 & 17.9 & 17.7 & 17.6 & 17.0 & 17.3 & 16.7 \\
\hline Field 5 & 23.8 & 22.6 & 22.2 & 17.6 & 17.8 & 18.1 & 16.7 & 16.8 & 16.2 \\
\hline Field 6 & 23.1 & 21.4 & 21.6 & 18.9 & 18.7 & 18.8 & 17.4 & 17.4 & 17.3 \\
\hline Field 7 & 21.4 & 20.8 & 20.8 & 19.1 & 18.1 & 18.7 & 17.1 & 16.2 & 16.2 \\
\hline Field 8 & 21.0 & 20.5 & 20.4 & 15.9 & 15.7 & 16.3 & 15.6 & 15.5 & 15.9 \\
\hline Field 9 & 21.2 & 20.7 & 21.4 & 16.1 & 15.8 & 16.0 & 16.2 & 15.5 & 15.4 \\
\hline Field 10 & 22.3 & 21.6 & 22.0 & 16.9 & 16.2 & 16.5 & 15.9 & 15.2 & 15.4 \\
\hline Field 11 & 22.7 & 20.7 & 20.0 & 18.7 & 17.7 & 18.0 & 17.8 & 15.8 & 15.5 \\
\hline Field 12 & 22.3 & 21.5 & 21.4 & 18.8 & 18.1 & 18.5 & 17.7 & 16.4 & 16.0 \\
\hline Field 13 & 22.1 & 20.9 & 20.4 & 18.6 & 18.0 & 18.2 & 15.6 & 15.7 & 15.6 \\
\hline Field 14 & 21.4 & 21.0 & 21.0 & 19.7 & 18.8 & 18.8 & 17.3 & 17.2 & 17.3 \\
\hline Field 15 & 22.3 & 21.3 & 21.2 & 17.7 & 17.9 & 18.1 & 16.5 & 16.4 & 16.7 \\
\hline Mean & 21.7 & 21.0 & 20.9 & 17.6 & 17.2 & 17.5 & 16.5 & 16.2 & 16.1 \\
\hline SED & 1.15 & 0.89 & 0.76 & 0.55 & 0.78 & 0.79 & 0.42 & 0.56 & 0.48 \\
\hline $\mathrm{CD}(\mathrm{p}=05)$ & 2.37 & 1.83 & 1.55 & 1.13 & 1.60 & 1.63 & 0.86 & 1.16 & 0.98 \\
\hline
\end{tabular}

Table.5 Effect of dew drops management practices on yield/ha (tonnes)

\begin{tabular}{|l|c|c|c|c|c|c|c|c|c|}
\hline \multirow{2}{*}{$\begin{array}{l}\text { Field } \\
\text { Number }\end{array}$} & \multicolumn{2}{|c|}{ Mobile sprinkler method (T3) } & \multicolumn{3}{c|}{ Rope method (T2) } & \multicolumn{3}{c|}{ Control (T1) } \\
\cline { 2 - 12 } & Rabi12 & Rabi 13 & Rabi 14 & Rabi 12 & Rabi 13 & Rabi 14 & Rabi 12 & Rabi 13 & Rabi 14 \\
\hline Field 1 & 13.1 & 13.8 & 13.5 & 11.5 & 12.5 & 12.2 & 12.1 & 11.4 & 10.9 \\
\hline Field 2 & 13.4 & 13.6 & 14.0 & 11.3 & 12.2 & 12.4 & 11.8 & 11.4 & 10.9 \\
\hline Field 3 & 14.1 & 13.6 & 14.0 & 11.5 & 12.6 & 12.5 & 12.3 & 11.3 & 10.9 \\
\hline Field 4 & 13.8 & 13.3 & 13.2 & 11.4 & 12.1 & 12.4 & 12.4 & 11.3 & 10.4 \\
\hline Field 5 & 12.9 & 13.5 & 13.8 & 11.4 & 12.6 & 12.0 & 12.6 & 11.1 & 10.7 \\
\hline Field 6 & 13.1 & 12.9 & 13.3 & 12.2 & 12.4 & 12.1 & 12.4 & 11.3 & 10.4 \\
\hline Field 7 & 12.7 & 13.3 & 12.9 & 12.5 & 12.0 & 12.3 & 12.6 & 11.5 & 10.2 \\
\hline Field 8 & 13.5 & 13.3 & 13.4 & 13.2 & 11.6 & 12.4 & 12.6 & 10.9 & 10.7 \\
\hline Field 9 & 13.6 & 12.9 & 13.3 & 12.7 & 12.3 & 12.2 & 12.8 & 10.6 & 10.6 \\
\hline Field 10 & 13.5 & 13.5 & 13.5 & 12.9 & 12.8 & 12.3 & 11.9 & 10.9 & 10.3 \\
\hline Field 11 & 13.4 & 13.3 & 13.4 & 12.9 & 12.6 & 12.5 & 11.6 & 10.5 & 10.8 \\
\hline Field 12 & 13.2 & 13.2 & 13.4 & 13.3 & 12.7 & 12.0 & 12.1 & 10.4 & 10.9 \\
\hline Field 13 & 13.4 & 13.3 & 13.2 & 12.7 & 12.5 & 12.2 & 11.5 & 11.5 & 10.8 \\
\hline Field 14 & 13.4 & 13.5 & 13.5 & 12.0 & 12.3 & 12.3 & 11.3 & 11.4 & 10.8 \\
\hline Field 15 & 13.1 & 13.3 & 13.2 & 12.5 & 12.1 & 12.2 & 11.9 & 11.5 & 10.6 \\
\hline Mean & $\mathbf{1 3 . 3}$ & $\mathbf{1 3 . 6}$ & $\mathbf{1 3 . 5}$ & $\mathbf{1 2 . 3}$ & $\mathbf{1 2 . 4}$ & $\mathbf{1 2 . 3}$ & $\mathbf{1 2 . 1}$ & $\mathbf{1 1 . 1}$ & $\mathbf{1 0 . 7}$ \\
\hline SED & 0.40 & 0.25 & 0.30 & 0.33 & 0.31 & 0.25 & 0.22 & 0.41 & 0.26 \\
\hline CD(p=05) & 0.83 & 0.51 & 0.61 & 0.67 & 0.64 & 0.53 & 0.46 & 0.85 & 0.54 \\
\hline
\end{tabular}




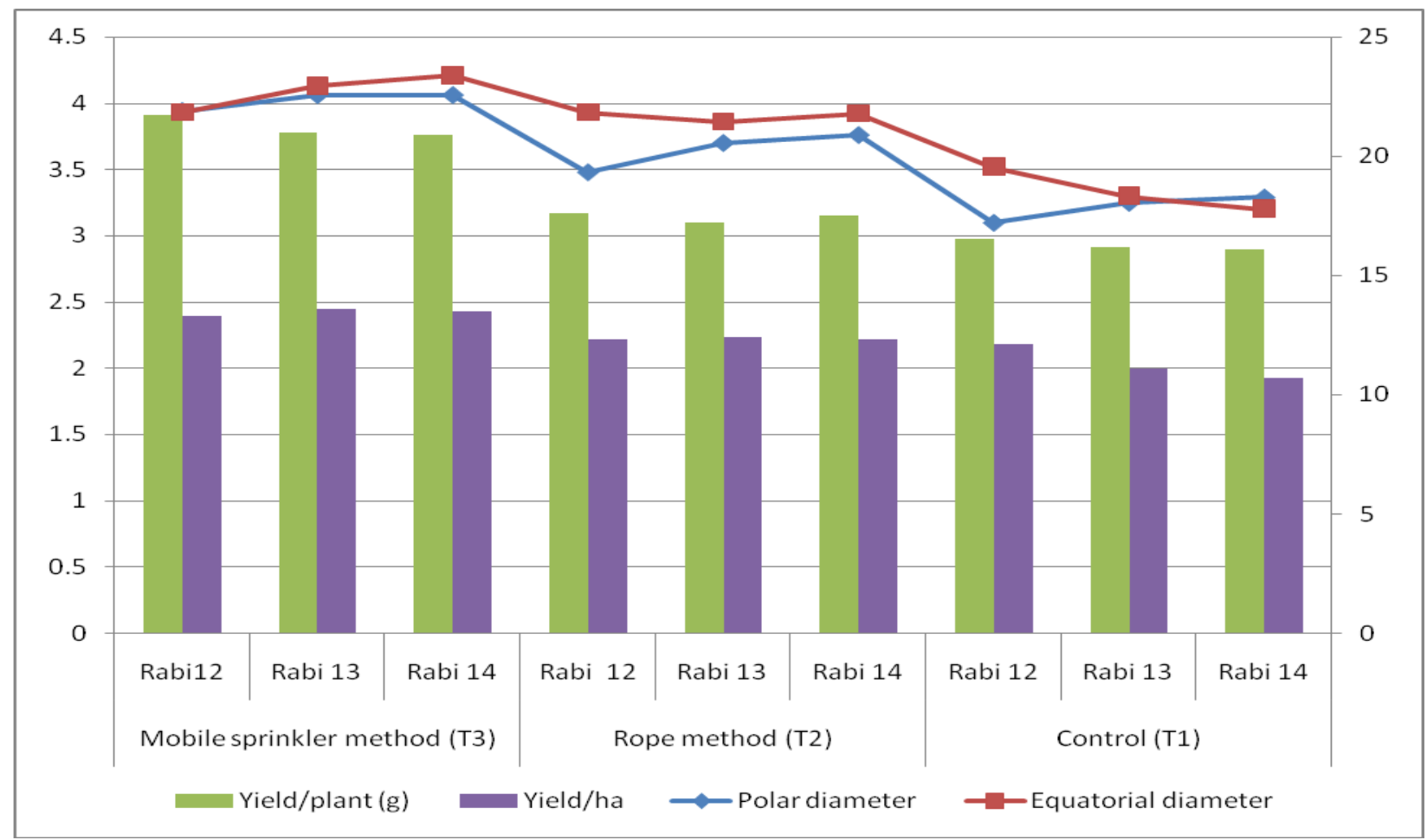

Fig.1 Effect of dew drop management practices in small onion on yield attributes

Consequently, early removal of dew drops resulted in continued vegetative growth as well as swelling of the bulbs till the crop matured for harvesting. In control the bulb size could not be developed as much as mobile sprinkler and rope method. In this case the production assimilates would not have been translocated towards developing sink bulbs due to tip drying of onion leaf sheath coupled with infestation by diseases. In want of sufficient metabolites the bulbs remained underdeveloped.

By these method the dew drops present on the tip of onion leaves got down and washed out and also purple blotch disease incidence was minimized. Demonstration plots recorded higher yield of $13.0 \mathrm{t} / \mathrm{ha}$ compared to farmers practice of $12.3 \mathrm{t} /$ ha with a $\mathrm{B}$ : C ratio (Benefit Cost Ratio) of 3.17:1 and 2.31:1 respectively. Mobile sprinkler method as one of the climate resilience practice followed against tip drying in small onion due to dew drops in selected village, which effectively protect the crop during adverse weather condition and also improved the quality of onion bulbs.70\% onion growers in this village, now widely used the rope method as well mobile sprinkler method for the management of tip drying due to dew drops. Especially the farm women easily adopted the rope technology during dew periods. Due to wide spread of this technology through training programmes, weather advisory services, mass media coverage, exposure visit by other onion farmers and by line department, $50 \%$ of farmers from major small onion cultivating blocks of Namakkal district viz., Valayapatti, Mohanur, Puduchathiram, Vennandhur, Rasipuram and Namagiripettai were successfully controlled the tip drying.

\section{References}

Anisuzzaman M, Ashrafuzzaman M, Ismail MR,Uddin MK and Rahim MA 2009. Planting timemulching effect on onion development and seedproduction. African Journal of Biotechnology8(3): 412-416. 
Anonymous 2014. State -wise estimates of area and production for onion in India. National Horticultural Board, Gurgaon, Haryana, India.

Anonymous. 2013. Crop production techniques of Horticultural crops. Horticultural College and Research Institute.Tamil Nadu Agricultural University, Coimbatore.

Aramirtham P 2000.Studies on certain aspects ofgrowth and development of seed settingaggregatum onion (Allium cepa var aggregatum) culture AcSP-1.MSc thesis, TamilNadu Agricultural University, Coimbatore, TN, India.

Bhatt, B., Srivastava, K. and Singh, M. P. (2004).Studies on the effect of foliar application of micronutrients on growth, yield and economics of tomato (Lycopersicon esculentum Mill).Prog.Hort., 36 (2): 331-334.

Boyhan GE, Diaz-Perez JC, Chris Hopkins C,Torrance RL and Hill CR 2008. Direct seedling short-day onions in southeastern Georgia. HortTechnology 18: 349-355.

Hansch R, Mendel RR.2009. Physiological functions of mineral micronutrients $(\mathrm{Cu}$, $\mathrm{Zn}, \mathrm{Mn}, \mathrm{Fe}, \mathrm{Ni}, \mathrm{Mo}, \mathrm{B}, \mathrm{Cl}$ ). Current
Opinion in Plant Biology 12:259-266.

Jilani MS 2004.Studies on the management strategiesfor bulb and seed production of different cultivarsof onion (Allium сера L).MSc thesis, NWFPAgricultural University, Peshawar, Pakistan.

Patil VK, Yadlod SS, Tambe TB, Narsude PB.2009. Effect of foliar application of micronutrients on flowering and fruit set of tomato (Lycopersicon esculentum Mill.) cv. Phule raja. International Journal of Agricultural Sciences 6, 164166.

Rohini N and P Paramaguru.2016. Seasons influence on bulb, seed yield and quality of aggregatum onion (Allium cepa var aggregatum). Int. J. Farm Sci., 6(1):174-183.

Ud-deen MU 2008.Effect of mother bulb size andplanting time on growth, bulb and seed yield ofonion. Bangladesh Journal of AgriculturalResearch 33(3): 531-537.

Umesh Acharya, Venkatesan K, Saraswathi T and.Subramanian K.S. (2015). Effect of Zinc and Boron application on growth and yield parameters of multiplier onion (Allium cepa L.var.aggregatum Don).Var.Co(On)5. International Journal of Research 2(1):757-765.

\section{How to cite this article:}

Sharmila Bharathi. C and Mohan. B. 2020. Effect of Management Practices to Tackle Tip Drying in Small Onion Due to Dew Drops in NICRA Village of Namakkal District of Tamil Nadu, India. Int.J.Curr.Microbiol.App.Sci. 9(05): 806-813.

doi: https://doi.org/10.20546/ijcmas.2020.905.089 